\title{
Tranexamic Acid is Associated with Reduced Mortality, Hemorrhagic Expansion, and Vascular Occlusive Events in Traumatic Brain Injury - Meta-analysis of Randomized Controlled Trials
}

Julius July ( $\square$ juliusjuly@yahoo.com )

Universitas Pelita Harapan Fakultas Kedokteran

Raymond Pranata

Universitas Pelita Harapan Fakultas Kedokteran

\section{Research article}

Keywords: Brain Trauma, Coagulopathy, Thromboembolism, Tranexamic Acid, Traumatic Brain Injury, Vascular Occlusive Events Posted Date: January 17th, 2020

DOI: https://doi.org/10.21203/rs.2.21121/v1

License: (c) (i) This work is licensed under a Creative Commons Attribution 4.0 International License. Read Full License

Version of Record: A version of this preprint was published at BMC Neurology on April 6th, 2020. See the published version at https://doi.org/10.1186/s12883-020-01694-4. 


\section{Abstract}

Introduction This systematic review and meta-analysis aimed to synthesize the latest evidence on the efficacy and safety of tranexamic acid (TXA) on traumatic brain injury (TBI).

Methods We performed a systematic literature search on topics that compared intravenous TXA to placebo in patients with TBI up until January 2019 from several electronic databases.

Results There were 30.522 patients from 7 studies. Meta-analysis showed that TXA was associated with reduced mortality (RR 0.92 $[0.88,0.97], p=0.002 ; 12: 0 \%)$ and hemorrhagic expansion (RR $0.79[0.64,0.97], p=0.03 ; 12: 0 \%)$. Both TXA and control group has a similar need for neurosurgical intervention $(p=0.87)$ and unfavourable Glasgow Outcome Scale (GOS) $(p=0.59)$. The rate for vascular occlusive events $(p=0.09)$, and its deep vein thrombosis subgroup $(p=0.23)$, pulmonary embolism subgroup $(p=1)$, stroke subgroup $(p=0.38)$, and myocardial infarction subgroup $(p=0.15)$ were similar in both groups. Subgroup analysis on RCTs with low risk of bias showed that TXA was associated with reduced mortality and hemorrhagic expansion. TXA was associated with reduced vascular occlusive events (RR $0.85[0.73,0.99], p=0.04 ; 12$ : 4\%). GRADE was performed for the RCT with low risk of bias subgroup, it showed a high certainty of evidence for lower mortality, less hemorrhage expansion, and similar need for neurosurgical intervention in TXA group compared to placebo group.

Conclusion TXA was associated with reduced mortality and hemorrhagic expansion but similar need for neurosurgical intervention and unfavorable GOS. Vascular occlusive events were slightly lower in TXA group on subgroup analysis of RCTs with low risk of bias.

\section{Introduction}

The worldwide incidence of traumatic brain injury (TBI) is approximately 69 million a year ${ }^{1}$, in which road injuries and falls contributed the most. ${ }^{2}$ Intracranial bleeding, which is frequently associated with TBI, increases mortality. ${ }^{3}$ Furthermore, the release of brain phospholipids and tissue factors due to TBI may precipitate coagulopathy. ${ }^{4}$ Coagulopathy developed in around one-third of patients with severe TBI which is associated with hemorrhage expansion, poor neurological outcome, and mortality. ${ }^{5-7}$

Tranexamic acid (TXA) can inhibit fibrinolysis by displacing plasminogen from fibrin and also inhibits enzymatic degradation by plasmin. TXA was also associated with enhanced clot strength, reduction in trauma-induced coagulopathy, and prevention of hyperfibrinolysis. ${ }^{8}$ However, clinical trials demonstrate conflicting results regarding the benefits of the TXA in TBI patients. ${ }^{9-12}$ The risk $^{-1}$ of thromboembolic complications is also uncertain as one study reported a significantly higher risk of pulmonary embolism (PE) in patients treated with TXA. ${ }^{9}$ These results pose a conundrum for TBI management. This systematic review and meta-analysis aimed to synthesize the latest evidence on the efficacy and safety of TXA on traumatic brain injury (TBI).

\section{Methods}

\section{Search Strategy}

We performed a systematic literature search on topics that compared intravenous TXA to placebo in patients with TBI with keywords ["tranexamic acid" and "traumatic brain injury"] and its synonym from inception up until January 2019 through PubMed, EuropePMC, Cochrane Central Database, ScienceDirect, ProQuest, ClinicalTrials.gov, and hand-sampling from potential articles cited by other studies. The records were then systematically evaluated using inclusion and exclusion criteria. We also perform hand-sampling from references of the included studies. Two researchers (J.J and R.P) independently performed an initial search, discrepancies were resolved by discussion. A Preferred Reporting Items for Systematic Reviews and Meta-Analyses (PRISMA) flowchart of the literature search strategy of studies was presented in Fig. 1.

\section{Selection criteria}

The inclusion criteria for this study are studies that compared intravenous TXA to placebo in patients with TBI. We include all related clinical researches/original articles and exclude animal studies, case reports, review articles, and non-English language articles.

Data Extraction 
Data extraction and quality assessment were done by two independent authors (J.J and R.P) using standardized extraction form which includes authors, year of publication, study design, sample size, subject characteristics, mortality, hemorrhagic expansion, need for neurosurgical intervention, unfavorable Glasgow outcome scale (GOS), deep vein thrombosis (DVT), PE, ischemic stroke, and myocardial infarction (Ml)

The primary outcome was mortality, hemorrhagic expansion, need for neurosurgical intervention, and unfavorable GOS. The secondary outcomes were vascular occlusive events defined as DVT, PE, ischemic stroke, and MI.

Statistical analysis

To perform the meta-analysis, we used RevMan version 5.3 software (Cochrane Collaboration) and STATA MP 16.0 (StataCorp LP). We used the risk ratio (RR) and a $95 \% \mathrm{Cl}$ as a pooled measure for dichotomous data. Inconsistency index $\left(\mathrm{I}^{2}\right)$ test, which ranges from 0 to $100 \%$, was used to assess heterogeneity across studies. A value above $50 \%$ or $p<0.10$ indicates statistically significant heterogeneity. We used the Mantel-Haenzsel method for RR, with the random-effect model regardless of heterogeneity. Small study effect was assessed using a regression-based test (Harbord test) for binary outcomes. Cochrane Risk of Bias Assessment tool (Cochrane Collaboration) will be used to assess the risk of bias for RCTs. Subgroup analysis was performed for RCTs with a low risk of bias. All P values were two-tailed with a statistical significance set at 0.05 or below. The certainty of the evidence for RCTs with low risk of bias was assessed by using the Guideline Development Tool by GRADEpro GDT.

\section{Results}

\section{Study Selection and Characteristics}

We found a total of 1704 results, and 1307 records remained after the removal of duplicates. 1285 records were excluded after screening the title/abstracts. After assessing 22 full-text for eligibility, we excluded 15 because 1) do not contain outcome of interest $(n=1), 2)$ specific on subdural and epidural hematoma $(n=1), 3)$ observational studies $(n=2), 4) \quad$ in general trauma patients $(n=1)$, 5.) unspecified location of injury $(n=1), 6)$ study protocol $(n=4), 7)$ analysis derived from an already included CRASH-3/CRASH-2 Trials $(n=3), 8)$ animal study $(n=1), 9)$ compliance of TXA use (observational) $(n=1)$. We included 7 studies in qualitative synthesis and 6 in meta-analysis. (Figure 1) There were a total of 30.522 patients from 7 studies. ${ }^{9-15}$ The TXA protocol was mostly $1 \mathrm{~g}$ TXA infused over 10 minutes, followed by IV infusion of $1 \mathrm{~g}$ over $8 \mathrm{~h}$. There was 1 study that gave bolus initially and another study that gave initial dose over 30 minutes. Matching placebo was specified in four studies, excluding Chakroun-Walha et al. and Jokar et al. Patients were around 30-40 years old and predominantly male. Time from injury to enrolment differs across studies. [Table 1]

\section{Efficacy}

Meta-analysis showed that TXA was associated with reduced mortality (RR $0.92[0.88,0.97], p=0.002 ; I^{2}: 0 \%, p=0.70$ ) [Figure 2A]. The rate of hemorrhagic expansion was lower in TXA group (RR 0.79 [0.64, 0.97], $p=0.03 ; 1^{2}: 0 \%, p=0.83$ ) [Figure 2B]. Both TXA and control group has a similar need for neurosurgical intervention ( $R R 0.99[0.92,1.07], p=0.87 ; l^{2}: 0 \%, p=0.43$ ). The unfavourable GOS on followup was similar in both groups (RR $\left.0.93[0.72,1.21], p=0.59 ; 1^{2}: 20 \%, p=0.29\right)$.

\section{Complications}

The rate for vascular occlusive events were similar in both TXA and placebo groups (RR $0.85[0.71,1.02], p=0.09 ; I^{2}: 21 \%, p=0.22$ ) [Figure 2C]. The risk for DVT subgroup (RR 0.82 [0.60, 1.13], $\left.p=0.23 ; I^{2}: 0 \%, p=0.45\right)$, PE subgroup (RR $1.00[0.60,1.66], p=1 ; I^{2}: 51 \%$, $p=0.11$ ), stroke subgroup (RR $\left.0.83[0.54,1.27], p=0.38 ; I^{2}: 41 \%, p=0.16\right)$, and $M I$ subgroup (RR $\left.0.75[0.50,1.11], p=0.15 ; I^{2}: 11 \%, p=0.32\right)$ were similar in both TXA and placebo group.

\section{Risk of Bias Assessment}

Risk of bias assessment using the Cochrane risk-of-bias tool for randomized trials showed two trial (Chakroun-Walha et al. and Jokar et al.) has a high risk of bias [Figure 3A]. The remaining 5 trials have a low risk of bias. The funnel-plot analysis showed a relatively symmetrical shape for mortality [Figure 3B] and symmetrical shape for hemorrhagic expansion [Figure 3C]. Regression-based Harbord's test for small-study effects was not statistically significant for all outcomes [Table 2]. 


\section{Subgroup Analysis for Randomized Controlled Trials with Low Risk of Bias}

In this subgroup analysis, Chakroun-Walha et al. and Jokar et al. were excluded due to high risk of bias. Meta-analysis showed that TXA was associated with reduced mortality ( $R R 0.92[0.87,0.97], p=0.001 ; 1^{2}: 0 \%, p=0.80$ ) [Figure 4A]. The rate of hemorrhagic expansion was lower in TXA group (RR $0.79[0.64,0.97], p=0.03 ; 1^{2}: 0 \%, p=0.83$ ) [Figure 4B]. Both TXA and control group has a similar need for neurosurgical intervention (RR $0.99[0.89,1.12], p=0.93 ; l^{2}: 5 \%, p=0.37$ ). The unfavourable Glasgow outcome scale on followup was similar in both groups ( $\left.R R 0.93[0.72,1.21], p=0.59 ; 1^{2}: 20 \%, p=0.29\right)$. The rate for vascular occlusive events were lower in TXA group (RR $0.85[0.73,0.99], p=0.04 ; I^{2}: 4 \%, p=0.40$ ) [Figure 4C]. The risk for DVT subgroup (RR $0.79[0.53,1.19], p=0.26 ; I^{2}: 25 \%$, $p=0.27$ ), PE subgroup (RR $\left.0.91[0.70,1.20], p=0.52 ; l^{2}: 0 \%, p=0.51\right)$, stroke subgroup (RR $\left.0.83[0.54,1.27], p=0.38 ; l^{2}: 41 \%, p=0.16\right)$, and MI subgroup (RR $0.75[0.50,1.11], p=0.15 ; I^{2}: 11 \%, p=0.32$ ) were similar in both TXA and placebo group.

\section{GRADE Approach}

Grading of Recommendations Assessment, Development, and Evaluation (GRADE) were performed for the RCT with low risk of bias subgroup, it showed a high certainty of the evidence for lower mortality, less hemorrhage expansion, and a similar need for neurosurgical intervention in TXA group compared to the placebo group. The certainty of evidence was moderate for the similar unfavorable GOS, less vascular occlusive events, a similar rate of DVT, and a similar rate of MI in the TXA group compared to the placebo group. (Table 3)

\section{Discussion}

This meta-analysis showed that TXA was associated with reduced mortality and hemorrhagic expansion. Vascular occlusive events were slightly lower in TXA group on a subgroup analysis of RCTs with a low risk of bias.

TXA is a trans-stereoisomer of 4-(aminomethyl)cyclohexane-carboxylic acid) binds to plasminogen via 5-lysine binding sites. ${ }^{16} \mathrm{It}$ prevent plasmin activation, reduces fibrinolysis, and stabilizes clot, without enhancing new clot formation. ${ }^{17}$ Early TXA administration $<60$ minutes has been shown to attenuate endothelial apoptosis and necrosis. ${ }^{18}$ TXA has been shown to modulate pulmonary inflammation in trauma-induced acute lung injury. ${ }^{19}$ In a TBI animal model, a potentially beneficial inflammatory and immune modulation were demonstrated after TXA administration. ${ }^{20}$ Furthermore, TXA was also shown to be associated with elevated immune activation in a post-TBI pneumonia animal model. ${ }^{21}$

Aside from the included studies, there was an observational study reported that TXA administration in patients with cerebral contusions or traumatic subarachnoid hemorrhage was independently associated with a reduced mortality rate. ${ }^{22}$ An RCT showed that TXA was associated with reduced intraoperative bleeding but not hemoglobin change in patients with epidural, subdural, and intraparenchymal hemorrhage. ${ }^{23,24}$

The confidence intervals of vascular occlusive events subgroup included the potential for important harm or benefit and the risk ratio < 0.75. Hence, there is a possible benefit of TXA on the incidence of DVT, PE, stroke, and MI. Although the pooled effect estimate displayed a null-effect, the larger sample size may be required because the incidence of these events might be too low to demonstrate any significant benefits. This possibility is further strengthened that by combining all of the subgroup, the vascular occlusive events are reduced in the TXA group. This finding however, might be subjected to potential confounders. In a meta-analysis of TXA use in intertrochanteric fracture, the rate of vascular occlusive events was similar in both TXA and control groups. ${ }^{25}$ If the benefits were proven to be true, it might be due to mechanism unrelated to anti-fibrinolysis in TBI patients, possibly due to its innate antiinflammatory, protection against endothelial injury, and platelet improving function. ${ }^{16,26}$ Thromboembolic events stem from endothelial injury and inflammation ${ }^{27,28}$, attenuation of these factors may prove to be protective.

The timing of administration was less certain, the mean time to injury was assessed in only three studies. CRASH-3 trial showed that the mortality benefits after adjustment were most pronounced when TXA was given $<3$ hours in mild-moderate Glasgow Coma Scale (GCS) score, however, mortality seemed to be the same in severe GCS score. ${ }^{13}$ Which is in accordance with the abovementioned study that the early administration is better. ${ }^{18}$ In a small RCT by Yutthakasemsunt et al., no mortality benefit was demonstrated in a mean time from injury of 7.1 hours. ${ }^{11}$ However, CRASH-2 trial that enrolls patients up to 8 hours after injury, showed the potential benefit of TXA. It should be noted that CRASH-2 trial excluded patients with isolated TBI and the benefits of TXA might be more pronounced in 
this trial. ${ }^{10}$ It is possible that if the analysis was conducted on patients with mild-moderate GCS and injury $<3$ hours, the benefits of TXA might be more pronounced, however, subgroup analysis or meta-regression is not possible in the current meta-analysis due to lack of available data.

Practical implications

TXA $1 \mathrm{~g}$ infused over 10 minutes, followed by IV infusion of $1 \mathrm{gram}$ over 8 hours, may be used to reduce the risk of hemorrhage expansion and slightly reduce mortality rate. There seemed to be no thrombotic repercussions of TXA. The timing was less certain, based on CRASH-3 study, earlier administration equals better outcomes and encouraged to be given within 3 hours. The benefits seemed to be demonstrable if given within 8 hours, however, further research is required before making a definite conclusion. Elderly patients and patients with high thromboembolic risk were not adequately studied and a cautious multidisciplinary consideration should be weighed.

Limitations

This systematic review and meta-analysis have several limitations; the risk of publication bias cannot be excluded even though the funnel plot was symmetrical because the number of studies was < 10. Meta-regression cannot be performed due to lack of studies, the meta-regression analysis may provide data on whether the result will be affected by covariates in the studies which are important to determine potential confounders in this study. Only a few studies reported the average time from injury to TXA administration and stratify them, hence, dose-response meta-analysis cannot be conducted. However, despite these limitations, the heterogeneity was low in the majority of analysis and the risk of bias was low in subgroup analysis providing a moderate-high certainty of evidence. The vascular occlusive events and their subgroups require further investigation, a double-blind RCT with a large sample size may demonstrate the benefits or confirm the null-effect. The research on the elderly and patients with high thromboembolic risk was also lacking.

\section{Conclusion}

TXA was associated with reduced mortality and hemorrhagic expansion but a similar need for neurosurgical intervention and unfavorable GOS. Vascular occlusive events were slightly lower in the TXA group on a subgroup analysis of RCTs with low risk of bias, but the incidence of DVT, PE, stroke, and MI individually were similar in both TXA and control groups. Large double-blind RCT(s) is still needed to assess the potential benefit on the vascular occlusive events outcome. We also encourage researches on the elderly and patients with high thromboembolic risk.

\section{Abbreviations}

DVT

Deep Vein Thrombosis

GCS

Glasgow Coma Scale

GOS

Glasgow Outcome Scale

MI

Myocardial Infarction

PE

Pulmonary Embolism

RCT

Randomized Controlled Trial

TBI

Traumatic Brain Injury

TXA

Tranexamic Acid

\section{Declarations}




\section{Ethics approval and consent to participate}

Not Applicable

\section{Consent for publication}

Not Applicable

\section{Availability of data and materials}

All data generated or analysed during this study are included in this published article

\section{Competing interests}

The authors declare that they have no competing interests

\section{Funding}

None

\section{Author's Contribution}

J.J and R.P conceived and designed the study and drafted the manuscript. J.J and R.P acquired the data and drafted the manuscript. J.J and R.P performed data extraction, interpreted the data, and performed extensive research on the topic. All authors contributed to the writing of the manuscript. R.P performed the statistical analysis.

\section{Acknowledgments}

None

\section{References}

1. Dewan MC, Rattani A, Gupta S, et al. Estimating the global incidence of traumatic brain injury. J Neurosurg. 2019;130(4):10801097. doi:10.3171/2017.10.JNS17352

2. James SL, Theadom A, Ellenbogen RG, et al. Global, regional, and national burden of traumatic brain injury and spinal cord injury, 1990-2016: a systematic analysis for the Global Burden of Disease Study 2016. Lancet Neurol. 2019;18(1):56-87. doi:10.1016/S1474-4422(18)30415-0

3. Perel P, Roberts I, Bouamra O, Woodford M, Mooney J, Lecky F. Intracranial bleeding in patients with traumatic brain injury: A prognostic study. BMC Emerg Med. 2009;9(1):15. doi:10.1186/1471-227X-9-15

4. Zehtabchi S, Soghoian S, Liu Y, et al. The association of coagulopathy and traumatic brain injury in patients with isolated head injury. Resuscitation. 2008;76(1):52-56. doi:10.1016/j.resuscitation.2007.06.024

5. Harhangi BS, Kompanje EJO, Leebeek FWG, Maas AIR. Coagulation disorders after traumatic brain injury. Acta Neurochir (Wien). 2008;150(2):165-175. doi:10.1007/s00701-007-1475-8

6. Allard CB, Scarpelini S, Rhind SG, et al. Abnormal Coagulation Tests Are Associated With Progression of Traumatic Intracranial Hemorrhage. J Trauma Inj Infect Crit Care. 2009;67(5):959-967. doi:10.1097/TA.0b013e3181ad5d37

7. Wafaisade A, Lefering R, Tjardes T, et al. Acute Coagulopathy in Isolated Blunt Traumatic Brain Injury. Neurocrit Care. 2010;12(2):211-219. doi:10.1007/s12028-009-9281-1

8. Gall L, Davenport R, Brohi K. Effect of early tranexamic acid on the coagulation system in patients with suspected traumatic haemorrhage: a prospective cohort study. Lancet. 2016;387:S46. doi:10.1016/S0140-6736(16)00433-5

9. Chakroun-Walha $\mathrm{O}$, Samet A, Jerbi M, et al. Benefits of the tranexamic acid in head trauma with no extracranial bleeding: a prospective follow-up of 180 patients. Eur J Trauma Emerg Surg. 2019;45(4):719-726. doi:10.1007/s00068-018-0974-z

10. Roberts I, Shakur H, Coats T, et al. The CRASH-2 trial: a randomised controlled trial and economic evaluation of the effects of tranexamic acid on death, vascular occlusive events and transfusion requirement in bleeding trauma patients. Heal Technol Assess. 2013;17(10):1-80. doi:10.3310/hta17100 
11. Yutthakasemsunt S, Kittiwatanagul W, Piyavechvirat P, Thinkamrop B, Phuenpathom N, Lumbiganon P. Tranexamic acid for patients with traumatic brain injury: a randomized, double-blinded, placebo-controlled trial. BMC Emerg Med. 2013;13(1):20. doi:10.1186/1471-227X-13-20

12. Fakharian E, Abedzadeh-kalahroudi M, Atoof F. Effect of Tranexamic Acid on Prevention of Hemorrhagic Mass Growth in Patients with Traumatic Brain Injury. World Neurosurg. 2018;109:e748-e753. doi:10.1016/j.wneu.2017.10.075

13. Crash- T. Effects of tranexamic acid on death, disability, vascular occlusive events and other morbidities in patients with acute traumatic brain injury (CRASH-3): a randomised, placebo-controlled trial. Lancet. 2019;394(10210):1713-1723. doi:10.1016/S0140-6736(19)32233-0

14. Jokar A, Ahmadi K, Salehi T, Sharif-Alhoseini M, Rahimi-Movaghar V. The effect of tranexamic acid in traumatic brain injury: A randomized controlled trial. Chinese J Traumatol. 2017;20(1):49-51. doi:10.1016/j.cjtee.2016.02.005

15. May S. Prehospital Tranexamic Acid Use for Traumatic Brain Injury (TXA). Clinicaltrials.gov. https://clinicaltrials.gov/ct2/show/results/NCT01990768?term=NCT01990768\&draw=2\&rank=1\&view=results. Published 2019. Accessed January 1, 2020.

16. Reed MR, Woolley LT. Uses of tranexamic acid. Contin Educ Anaesth Crit Care Pain. 2015;15(1):32-37. doi:10.1093/bjaceaccp/mku009

17. Lier H, Maegele M, Shander A. Tranexamic Acid for Acute Hemorrhage. Anesth Analg. 2019;129(6):1574-1584. doi:10.1213/ANE.0000000000004389

18. Diebel LN, Martin J V., Liberati DM. Early tranexamic acid administration ameliorates the endotheliopathy of trauma and shock in an in vitro model. J Trauma Acute Care Surg. 2017;82(6):1080-1086. doi:10.1097/TA.0000000000001445

19. Teng Y, Feng C, Liu Y, Jin H, Gao Y, Li T. Anti-inflammatory effect of tranexamic acid against trauma-hemorrhagic shock-induced acute lung injury in rats. Exp Anim. 2018;67(3):313-320. doi:10.1538/expanim.17-0143

20. Draxler DF, Daglas M, Fernando A, et al. Tranexamic acid modulates the cellular immune profile after traumatic brain injury in mice without hyperfibrinolysis. J Thromb Haemost. 2019;17(12):2174-2187. doi:10.1111/jth.14603

21. Draxler DF, Awad MM, Hanafi G, et al. Tranexamic Acid Influences the Immune Response, but not Bacterial Clearance in a Model of Post-Traumatic Brain Injury Pneumonia. J Neurotrauma. 2019;36(23):3297-3308. doi:10.1089/neu.2018.6030

22. Chan DYC, Tsang ACO, Li LF, et al. Improving Survival with Tranexamic Acid in Cerebral Contusions or Traumatic Subarachnoid Hemorrhage: Univariate and Multivariate Analysis of Independent Factors Associated with Lower Mortality. World Neurosurg. 2019;125:e665-e670. doi:10.1016/j.wneu.2019.01.145

23. Ebrahimi P, Mozafari J, Ilkhchi RB, Hanafi MG, Mousavinejad M. Intravenous Tranexamic Acid for Subdural and Epidural Intracranial Hemorrhage: Randomized, Double-Blind, Placebo-Controlled Trial. Rev Recent Clin Trials. 2019;14(4):286-291. doi:10.2174/1574887114666190620112829

24. Mousavinejad M, Mozafari J, Ilkhchi RB, Hanafi MG, Ebrahimi P. Intravenous Tranexamic Acid for Brain Contusion with Intraparenchymal Hemorrhage: Randomized, Double-blind, Placebo-controlled Trial. Rev Recent Clin Trials. $2019 ; 14$. doi:10.2174/1574887114666191118111826

25. Yu X, Wang J, Wang X, Xie L, Chen C, Zheng W. The efficacy and safety of tranexamic acid in the treatment of intertrochanteric fracture: an updated meta-analysis of 11 randomized controlled trials. J Thromb Thrombolysis. January 2020. doi:10.1007/s11239-019-02034-1

26. Levy JH. Antifibrinolytic therapy: new data and new concepts. Lancet. 2010;376(9734):3-4. doi:10.1016/S0140-6736(10)60939-7

27. Davies MJ. CORONARY DISEASE: The pathophysiology of acute coronary syndromes. Heart. 2000;83(3):361-366. doi:10.1136/heart.83.3.361

28. Behravesh S, Hoang P, Nanda A, et al. Pathogenesis of Thromboembolism and Endovascular Management. Thrombosis. 2017;2017:1-13. doi:10.1155/2017/3039713

\section{Tables}

Table 1. Studies Included in the Systematic Review 


\begin{tabular}{|c|c|c|c|c|c|c|c|c|c|}
\hline Authors & $\begin{array}{l}\text { Study } \\
\text { Design }\end{array}$ & TXA Protocol & $\begin{array}{l}\text { Matching } \\
\text { Placebo }\end{array}$ & $\begin{array}{l}\text { Sample Size } \\
\text { (n) }\end{array}$ & $\begin{array}{l}\text { Age } \\
\text { (mean } \pm S D, \\
\text { years) }\end{array}$ & $\begin{array}{l}\text { Male } \\
\text { (\%) }\end{array}$ & $\begin{array}{l}\text { Time } \\
\text { from } \\
\text { Injury } \\
\text { Eligibility } \\
\text { (hours) }\end{array}$ & $\begin{array}{l}\text { Mean } \\
\text { Time } \\
\text { from } \\
\text { Injury } \\
\text { (hours) }\end{array}$ & Funding \\
\hline CRASH-3 2019 & $\begin{array}{l}\text { Double- } \\
\text { blind } \\
\text { RCT }\end{array}$ & $\begin{array}{l}1 \mathrm{~g} \text { TXA } \\
\text { infused over } \\
10 \mathrm{~min}, \\
\text { followed by } \\
\text { IV infusion } \\
\text { of } 1 \mathrm{~g} \text { over } 8 \\
\mathrm{~h}\end{array}$ & $\begin{array}{l}\text { Matching } \\
\text { Placebo } \\
\text { (NS) }\end{array}$ & $\begin{array}{l}9127 \\
(4613 / 4514)\end{array}$ & $\begin{array}{l}41.7 \pm 19.0 \\
\text { vs } \\
41.9 \pm 19.0\end{array}$ & $\begin{array}{l}80 \text { vs } \\
80\end{array}$ & $\begin{array}{l}\text { Originally } \\
8, \\
\text { changed } \\
\text { to } 3 \\
\text { hours }\end{array}$ & $1.9 \pm 0.7$ & $\begin{array}{l}\text { National } \\
\text { Institute for } \\
\text { Health } \\
\text { Research } \\
\text { Health } \\
\text { Technology } \\
\text { Assessment, } \\
\text { JP Moulton } \\
\text { Charitable } \\
\text { Trust, } \\
\text { Department } \\
\text { of Health and } \\
\text { Social Care, } \\
\text { Department } \\
\text { for } \\
\text { International } \\
\text { Development, } \\
\text { Global } \\
\text { Challenges } \\
\text { Research } \\
\text { Fund, } \\
\text { Medical } \\
\text { Research } \\
\text { Council, and } \\
\text { Wellcome } \\
\text { Trust (Joint } \\
\text { Global Health } \\
\text { Trials } \\
\text { scheme). }\end{array}$ \\
\hline $\begin{array}{l}\text { NCT01990768 } \\
\text { (Bolus- } \\
\text { Maintenance } \\
\text { Group) }\end{array}$ & $\begin{array}{l}\text { Double- } \\
\text { blind } \\
\text { RCT }\end{array}$ & $\begin{array}{l}1 \mathrm{~g} \mathrm{TXA} \\
\text { bolus } \\
\text { (prehospital), } \\
\text { followed by } \\
\text { IV infusion } \\
\text { of } 1 \mathrm{~g} \text { over } 8 \\
\mathrm{~h}\end{array}$ & $\begin{array}{l}\text { Matching } \\
\text { Placebo } \\
\text { (NS) }\end{array}$ & $\begin{array}{l}621 \\
(312 / 309)\end{array}$ & $\begin{array}{l}39 \\
(26-57) \text { vs } \\
36 \\
(25-55)\end{array}$ & $\begin{array}{l}73 \text { vs } \\
75\end{array}$ & 2 & $\mathrm{~N} / \mathrm{A}$ & $\begin{array}{l}\text { National } \\
\text { Heart, Lung, } \\
\text { and Blood } \\
\text { Institute; } \\
\text { United States } \\
\text { Army } \\
\text { Medical } \\
\text { Research } \\
\text { Acquisition } \\
\text { Activity }\end{array}$ \\
\hline $\begin{array}{l}\text { Chakroun-Walha } \\
2018\end{array}$ & $\begin{array}{l}\text { Open- } \\
\text { label } \\
\text { RCT }\end{array}$ & $\begin{array}{l}1 \mathrm{~g} \text { TXA } \\
\text { infused over } \\
10 \text { min, } \\
\text { followed by } \\
\text { IV infusion } \\
\text { of } 1 \mathrm{~g} \text { over } 8 \\
\text { h }\end{array}$ & $\begin{array}{l}\text { None (no } \\
\text { TXA) }\end{array}$ & $180(96 / 84)$ & $\begin{array}{l}44 \pm 20 \text { vs } \\
39 \pm 18\end{array}$ & $\begin{array}{l}\text { M/F } \\
\text { Ratio: } \\
11 \text { vs } \\
8.3\end{array}$ & 24 & $\mathrm{~N} / \mathrm{A}$ & None \\
\hline Fakharian 2017 & $\begin{array}{l}\text { Double- } \\
\text { blind } \\
\text { RCT }\end{array}$ & $\begin{array}{l}1 \mathrm{~g} \text { TXA } \\
\text { infused over } \\
10 \text { min, } \\
\text { followed by } \\
\text { IV infusion } \\
\text { of } 1 \mathrm{~g} \text { over } 8 \\
\text { h }\end{array}$ & $\begin{array}{l}\text { Matching } \\
\text { Placebo } \\
\text { (NS) }\end{array}$ & $149(74 / 75)$ & $\begin{array}{l}42.3 \pm 18.3 \\
\text { vs } \\
39.3 \pm 18.1\end{array}$ & $\begin{array}{l}91 \text { vs } \\
88\end{array}$ & 8 & $\mathrm{~N} / \mathrm{A}$ & $\begin{array}{l}\text { Kashan } \\
\text { University of } \\
\text { Medical } \\
\text { Sciences }\end{array}$ \\
\hline Jokar 2017 & $\begin{array}{l}\text { Single- } \\
\text { blind } \\
\text { RCT }\end{array}$ & $\begin{array}{l}1 \mathrm{~g} \text { TXA } \\
\text { infused over } \\
10 \text { min, } \\
\text { followed by } \\
\text { IV infusion } \\
\text { of } 1 \mathrm{~g} \text { over } 8\end{array}$ & $\begin{array}{l}\text { Unobvious } \\
\text { Placebo }\end{array}$ & $80(40 / 40)$ & $\begin{array}{l}35.4 \pm 14.6 \\
\text { vs } \\
36.2 \pm 14.9\end{array}$ & $\begin{array}{l}40 \text { vs } \\
35\end{array}$ & 2 & $\mathrm{~N} / \mathrm{A}$ & $\begin{array}{l}\text { Arak } \\
\text { University of } \\
\text { Medical } \\
\text { Sciences }\end{array}$ \\
\hline
\end{tabular}




\begin{tabular}{|c|c|c|c|c|c|c|c|c|c|}
\hline & & $\mathrm{h}$ & & & & & & & \\
\hline CRASH-2 2013 & $\begin{array}{l}\text { Double-- } \\
\text { blind } \\
\text { RCT }\end{array}$ & $\begin{array}{l}1 \mathrm{~g} \text { TXA } \\
\text { infused over } \\
10 \text { min, } \\
\text { followed by } \\
\text { IV infusion } \\
\text { of } 1 \mathrm{~g} \text { over } 8 \\
\mathrm{~h}\end{array}$ & $\begin{array}{l}\text { Matching } \\
\text { Placebo } \\
\text { (NS) }\end{array}$ & $10060 / 10067$ & $\begin{array}{l}34.6 \pm 14.1 \\
\text { vs } \\
34.5 \pm 14.4\end{array}$ & $\begin{array}{l}84 \text { vs } \\
84\end{array}$ & 8 & $2.9 \pm 2.6$ & $\begin{array}{l}\text { Health } \\
\text { Technology } \\
\text { Assessment } \\
\text { Programme; } \\
\text { National } \\
\text { Institute for } \\
\text { Health } \\
\text { Research } \\
\end{array}$ \\
\hline $\begin{array}{l}\text { Yutthakasemsunt } \\
2013\end{array}$ & $\begin{array}{l}\text { Double- } \\
\text { blind } \\
\text { RCT }\end{array}$ & $\begin{array}{l}1 \mathrm{~g} \text { TXA } \\
\text { infused over } \\
30 \text { min, } \\
\text { followed by } \\
\text { IV infusion } \\
\text { of } 1 \mathrm{~g} \text { over } 8 \\
\text { h }\end{array}$ & $\begin{array}{l}\text { Matching } \\
\text { Placebo } \\
\text { (Sterile } \\
\text { Water) }\end{array}$ & $\begin{array}{l}238 \\
(120 / 118)\end{array}$ & $\begin{array}{l}34.8 \pm 16.0 \\
\text { vs } \\
34.1 \pm 15.3\end{array}$ & $\begin{array}{l}86 \text { vs } \\
91\end{array}$ & 8 & $7.1 \pm 1.29$ & $\begin{array}{l}\text { The Thailand } \\
\text { Research } \\
\text { Fund }\end{array}$ \\
\hline
\end{tabular}

NS: Normal Saline; RCT: Randomized Controlled Trials; SD: Standard Deviation; TXA: Tranexamic Acid

Table 2. Summary of Meta-analysis

\begin{tabular}{|c|c|c|c|c|}
\hline Outcomes & $\begin{array}{l}\text { Risk Ratio (95\% Confidence Interval), } \\
\text { p-value }\end{array}$ & $\begin{array}{l}\text { Heterogeneity }\left(I^{2}\right), p- \\
\text { value }\end{array}$ & $\begin{array}{l}\text { Harbord's } \\
\text { Test }\end{array}$ & $\begin{array}{l}\text { Number of } \\
\text { Studies }\end{array}$ \\
\hline Mortality & $0.92[0.88,0.97], 0.002$ & $0 \%, 0.70$ & 0.671 & 6 \\
\hline Hemorrhagic Expansion & $0.79[0.64,0.97], 0.03$ & $0 \%, 0.83$ & 0.623 & 4 \\
\hline $\begin{array}{l}\text { Need for Neurosurgical } \\
\text { Intervention }\end{array}$ & $0.99[0.92,1.07], 0.87$ & $0 \%, 0.43$ & 0.332 & 5 \\
\hline $\begin{array}{l}\text { Unfavourable Glasgow Outcome } \\
\text { Scale }\end{array}$ & $0.93[0.72,1.21], 0.59$ & $20 \%, 0.29$ & 0.106 & 3 \\
\hline Vascular Occlusive Events* & $0.85[0.71,1.02], 0.09$ & $21 \%, 0.22$ & 0.513 & 5 \\
\hline DVT & $0.82[0.60,1.13], 0.23$ & $0 \%, 0.45$ & 0.405 & 5 \\
\hline $\mathrm{PE}$ & $1.00[0.60,1.66], 1$ & $51 \%, 0.11$ & 0.726 & 5 \\
\hline Stroke & $0.83[0.54,1.27], 0.38$ & $41 \%, 0.16$ & 0.105 & 4 \\
\hline $\mathrm{Ml}$ & $0.75[0.50,1.11], 0.15$ & $11 \%, 0.32$ & 0.124 & 3 \\
\hline \multicolumn{5}{|c|}{ RCT with Low Risk of Bias Subgroup } \\
\hline Mortality & $0.92[0.87,0.97], 0.001$ & $0 \%, 0.80$ & 0.795 & 5 \\
\hline Hemorrhagic Expansion & $0.79[0.64,0.97], 0.03$ & $0 \%, 0.83$ & 0.623 & 4 \\
\hline $\begin{array}{l}\text { Need for Neurosurgical } \\
\text { Intervention }\end{array}$ & $0.99[0.89,1.12], 0.93$ & $5 \%, 0.37$ & 0.534 & 4 \\
\hline $\begin{array}{l}\text { Unfavourable Glasgow Outcome } \\
\text { Scale }\end{array}$ & $0.93[0.72,1.21], 0.59$ & $20 \%, 0.29$ & 0.106 & 3 \\
\hline Vascular Occlusive Events* & $0.85[0.73,0.99], 0.04$ & $4 \%, 0.40$ & 0.084 & 4 \\
\hline DVT & $0.79[0.53,1.19], 0.26$ & $25 \%, 0.27$ & 0.170 & 4 \\
\hline $\mathrm{PE}$ & $0.91[0.70,1.20], 0.52$ & $0 \%, 0.51$ & 0.383 & 4 \\
\hline Stroke & $0.83[0.54,1.27], 0.38$ & $41 \%, 0.16$ & 0.105 & 4 \\
\hline $\mathrm{Ml}$ & $0.75[0.50,1.11], 0.15$ & $11 \%, 0.32$ & 0.124 & 3 \\
\hline
\end{tabular}

*indicates DVT+PE+Stroke+MI

DVT: Deep Vein Thrombosis; Ml: Myocardial Infarction; PE: Pulmonary Embolism

Table 3. GRADE Approach for RCTs with low risk of bias 
№ of Study design Risk of Inconsistency Indirectness Imprecision bias
Other considerations
Tranexamic

Acid

placebo

Relative

(95\% Cl)

Absolute (95\% Cl)

Mortality

\begin{tabular}{|c|c|c|c|c|c|c|c|c|c|c|c|}
\hline 5 & $\begin{array}{c}\text { randomised } \\
\text { trials }\end{array}$ & not serious & not serious & not serious & not serious & none & $\begin{array}{c}2385 / 15179 \\
(15.7 \%)\end{array}$ & $\begin{array}{c}2575 / 15083 \\
(17.1 \%)\end{array}$ & $\begin{array}{c}\text { RR } 0.92 \\
(0.87 \text { to } \\
0.97)\end{array}$ & $\begin{array}{c}14 \text { fewer per } 1,000 \\
\text { (from } 22 \text { fewer to } 5 \\
\text { fewer) }\end{array}$ & $\begin{array}{c}\oplus \bigoplus \bigoplus \oplus \\
\mathrm{HIGH}\end{array}$ \\
\hline
\end{tabular}

Hemorrhage Expansion

\begin{tabular}{|c|c|c|c|c|c|c|c|c|c|c|c|}
\hline 4 & $\begin{array}{l}\text { randomised } \\
\text { trials }\end{array}$ & not serious & not serious & not serious & not serious & none & $106 / 471(22.5 \%)$ & $135 / 467(28.9 \%)$ & $\begin{array}{c}\text { RR } 0.78 \\
(0.63 \text { to } \\
0.97)\end{array}$ & $\begin{array}{c}64 \text { fewer per } 1,000 \\
\text { (from } 107 \text { fewer to } 9 \\
\text { fewer) }\end{array}$ & $\begin{array}{c}\oplus \oplus \bigoplus \oplus \\
\mathrm{HIGH}\end{array}$ \\
\hline
\end{tabular}

Need for Neurosurgical Intervention

\begin{tabular}{|c|c|c|c|c|c|c|c|c|c|c|c|}
\hline 4 & $\begin{array}{c}\text { randomised } \\
\text { trials }\end{array}$ & not serious & not serious & not serious & not serious & none & $\begin{array}{c}1113 / 10566 \\
(10.5 \%)\end{array}$ & $\begin{array}{c}1125 / 10569 \\
(10.6 \%)\end{array}$ & $\begin{array}{l}\text { RR } 0.99 \\
(0.89 \text { to } \\
1.12)\end{array}$ & $\begin{array}{c}1 \text { fewer per } 1,000 \\
\text { (from } 12 \text { fewer to } 13 \\
\text { more) }\end{array}$ & $\begin{array}{c}\oplus \oplus \bigoplus \bigoplus \\
\mathrm{HIGH}\end{array}$ \\
\hline
\end{tabular}

Unfavourable GOS

\begin{tabular}{|c|c|c|c|c|c|c|c|c|c|c|c|}
\hline 3 & $\begin{array}{l}\text { randomised } \\
\text { trials }\end{array}$ & not serious & not serious & not serious & serious $^{a}$ & none & $137 / 455$ (30.1\%) & $147 / 463$ (31.7\%) & $\begin{array}{c}\text { RR } 0.93 \\
(0.72 \text { to } \\
1.21)\end{array}$ & $\begin{array}{c}22 \text { fewer per } 1,000 \\
\text { (from } 89 \text { fewer to } 67 \\
\text { more) }\end{array}$ & $\begin{array}{l}\oplus \oplus \bigoplus \bigcirc \\
\text { MODERATE }\end{array}$ \\
\hline
\end{tabular}

Vascular Occlusive Events

\begin{tabular}{|c|c|c|c|c|c|c|c|c|c|c|c|}
\hline 4 & $\begin{array}{c}\text { randomised } \\
\text { trials }\end{array}$ & not serious & serious $^{b}$ & not serious & not serious & none & $\begin{array}{c}328 / 67281 \\
(0.5 \%)\end{array}$ & $\begin{array}{c}387 / 66981 \\
(0.6 \%)\end{array}$ & $\begin{array}{c}\text { RR } 0.85 \\
(0.73 \text { to } \\
0.99)\end{array}$ & $\begin{array}{c}1 \text { fewer per } 1,000 \\
\text { (from } 2 \text { fewer to } 0 \\
\text { fewer) }\end{array}$ & $\begin{array}{l}\oplus \oplus \oplus \bigcirc \\
\text { MODERATE }\end{array}$ \\
\hline
\end{tabular}

Vascular Occlusive Events - DVT

\begin{tabular}{|c|c|c|c|c|c|c|c|c|c|c|c|}
\hline 4 & $\begin{array}{l}\text { randomised } \\
\text { trials }\end{array}$ & not serious & not serious & not serious & serious $^{a}$ & none & $67 / 16851(0.4 \%)$ & $82 / 16774(0.5 \%)$ & $\begin{array}{c}\text { RR } 0.79 \\
(0.53 \text { to } \\
1.19)\end{array}$ & $\begin{array}{c}1 \text { fewer per } 1,000 \\
\text { (from } 2 \text { fewer to } 1 \\
\text { more) }\end{array}$ & $\begin{array}{l}\bigoplus \oplus \bigoplus \bigcirc \\
\text { MODERATE }\end{array}$ \\
\hline
\end{tabular}

Vascular Occlusive Events - MI

\begin{tabular}{|c|c|c|c|c|c|c|c|c|c|c|c|}
\hline 3 & $\begin{array}{c}\text { randomised } \\
\text { trials }\end{array}$ & not serious & not serious & not serious & serious $^{a}$ & none & $56 / 16731(0.3 \%)$ & $76 / 16656(0.5 \%)$ & $\begin{array}{l}\text { RR } 0.75 \\
(0.50 \text { to } \\
1.11)\end{array}$ & $\begin{array}{c}1 \text { fewer per } 1,000 \\
\text { (from } 2 \text { fewer to } 1 \\
\text { more) }\end{array}$ & $\begin{array}{c}\oplus \oplus \oplus \bigcirc \\
\text { MODERATE }\end{array}$ \\
\hline
\end{tabular}

CI: Confidence interval; RR: Risk ratio; TXA: Tranexamic Acid

\section{Explanations}

a. Confidence intervals included potential for important harm or benefit and the risk ratio $<0.75$.

b. Heterogeneity $>40 \%$

\section{Figures}




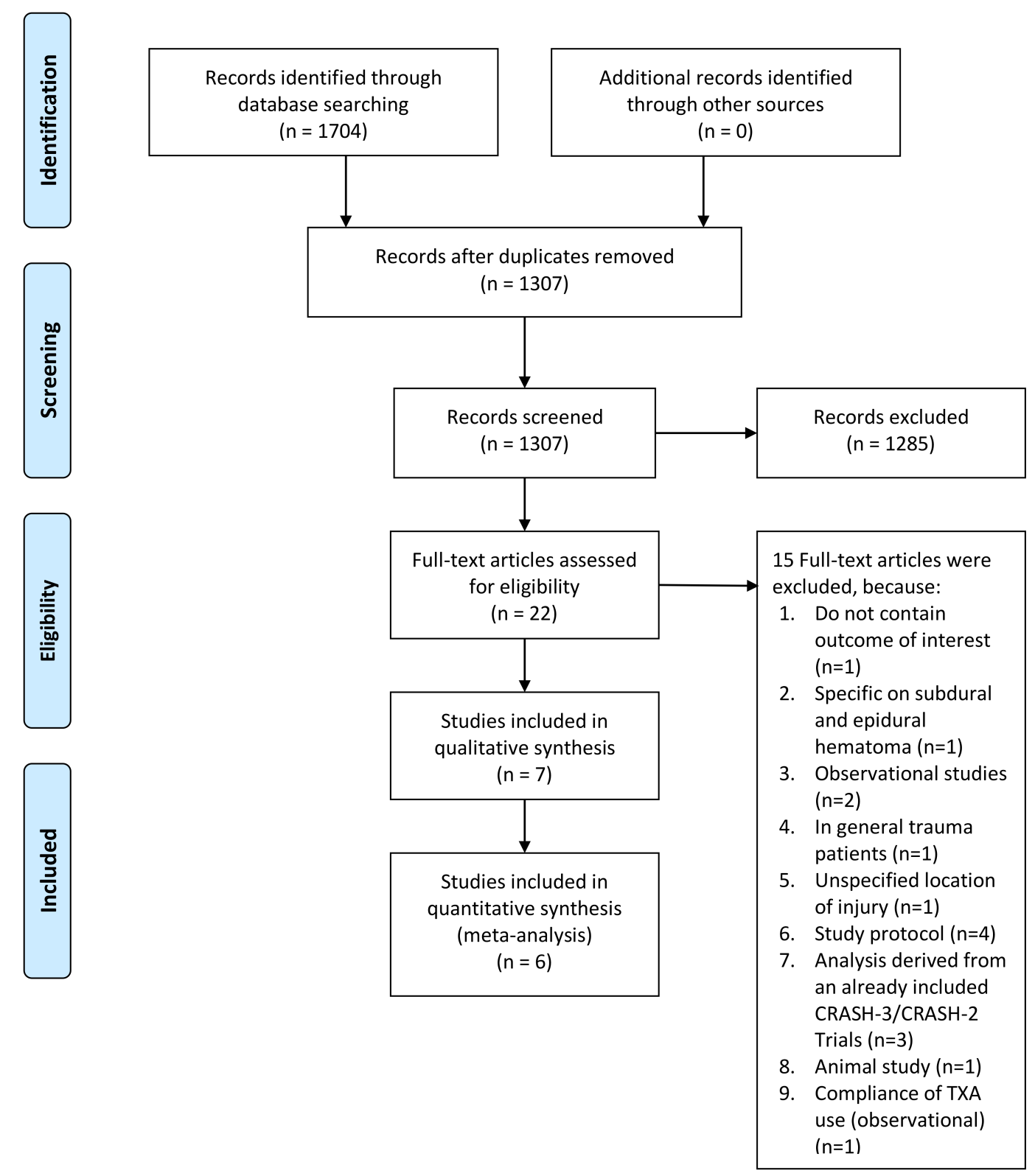

\section{Figure 1}

Study flow diagram 
A
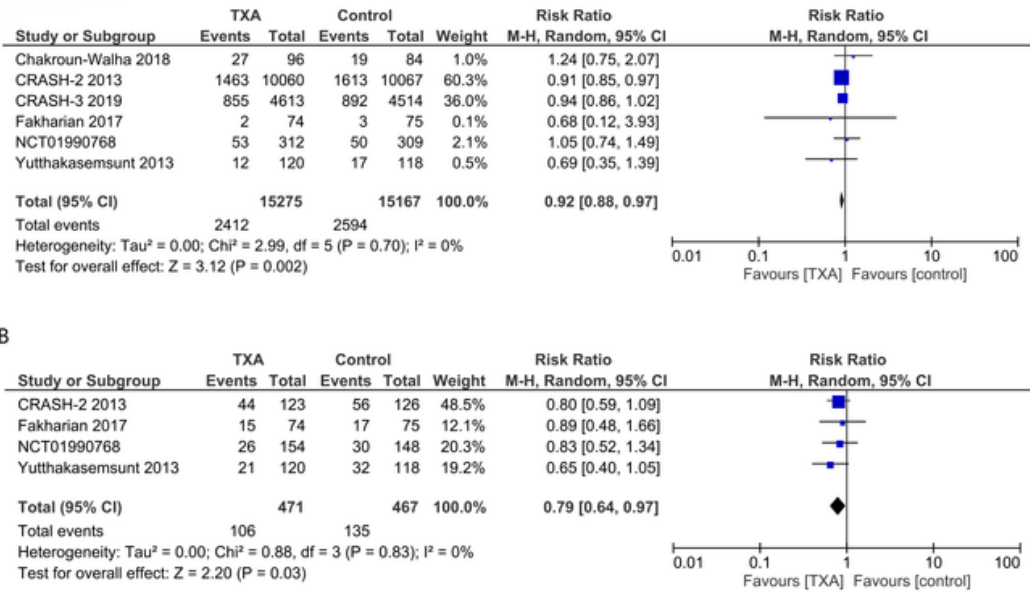

c

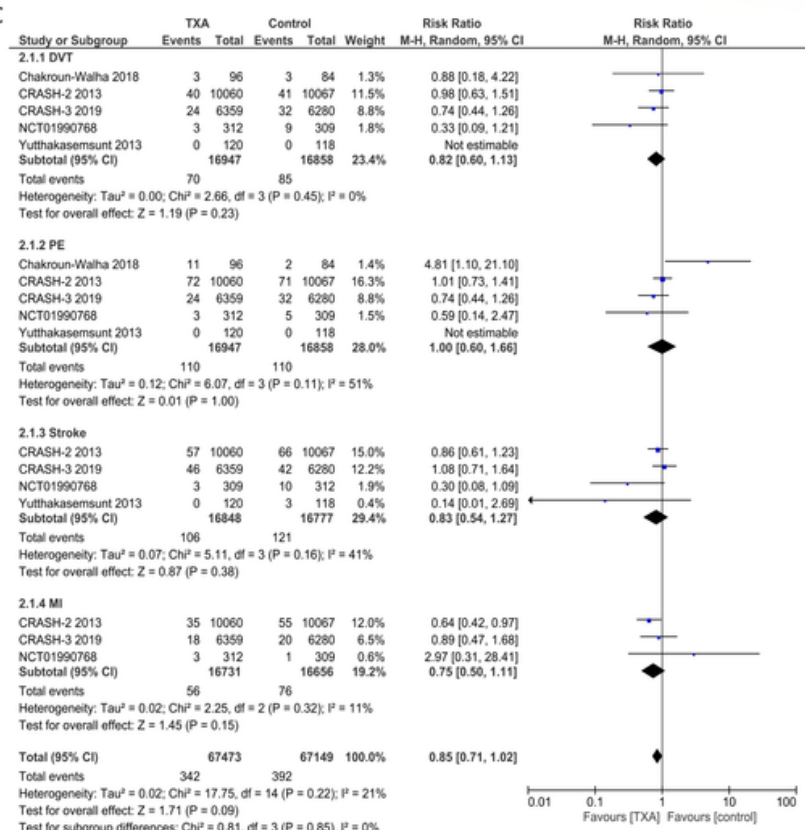

Figure 2

Meta-analysis for tranexamic acid versus placebo. Figure 2A demonstrated a lower mortality rate in TXA group. Figure 2B showed hemorrhagic expansion was less in TXA group. Vascular occlusive events (Figure 4C), defined as DVT+PE+stroke+MI was similar in both groups. Description= DVT: Deep Vein Thrombosis; MI: Myocardial Infarction; PE: Pulmonary Embolism; TXA: Tranexamic Acid. 


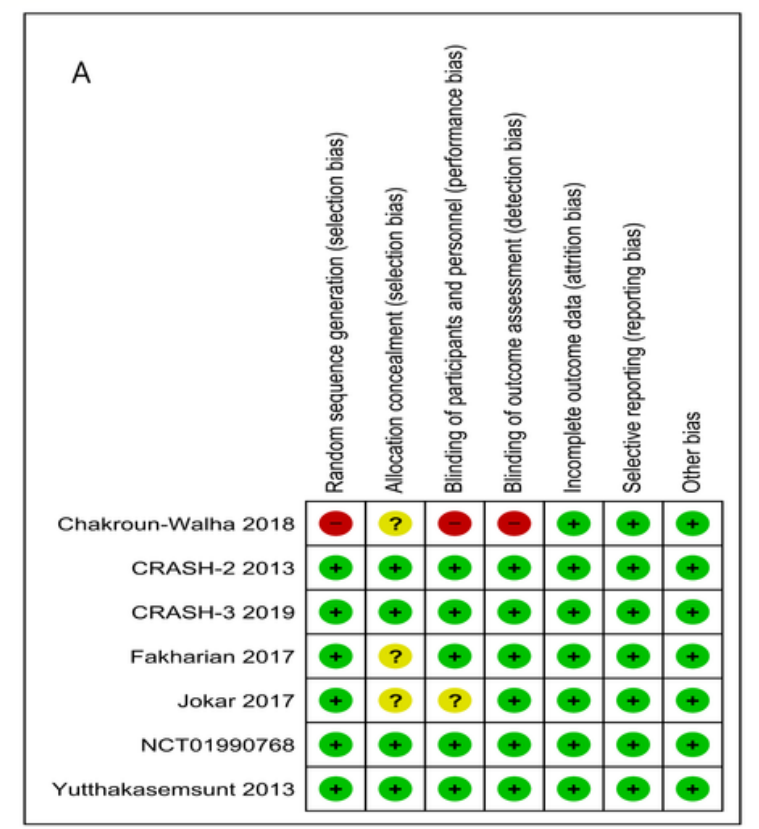

B
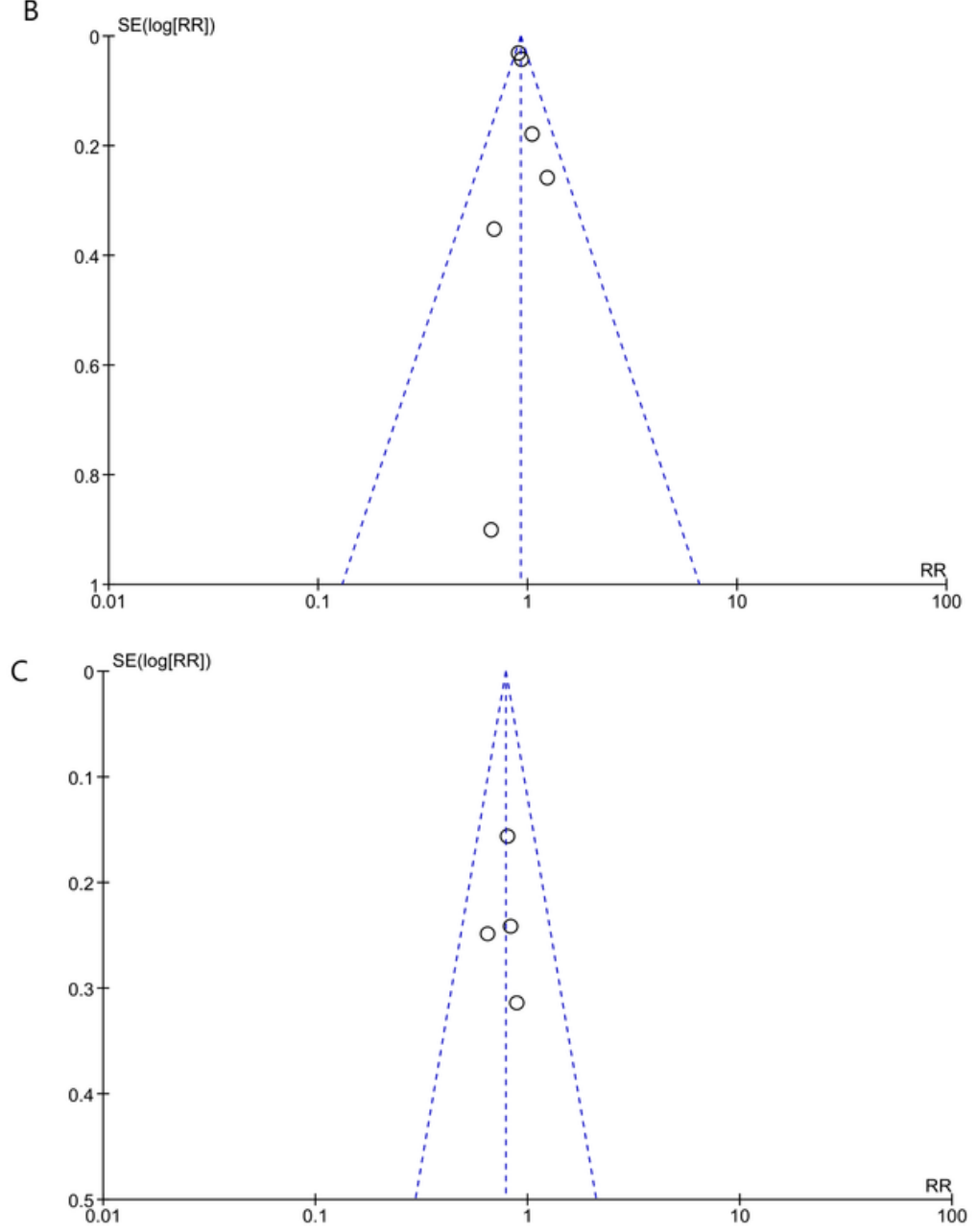

\section{Figure 3}

Risk of Bias Assessment. Figure 3A showed Cochrane Risk of Bias Assessment for Randomized Controlled Trials. Figure 3B and Figure $3 \mathrm{C}$ showed funnel-plot analysis for mortality and hemorrhagic expansion respectively. 
A

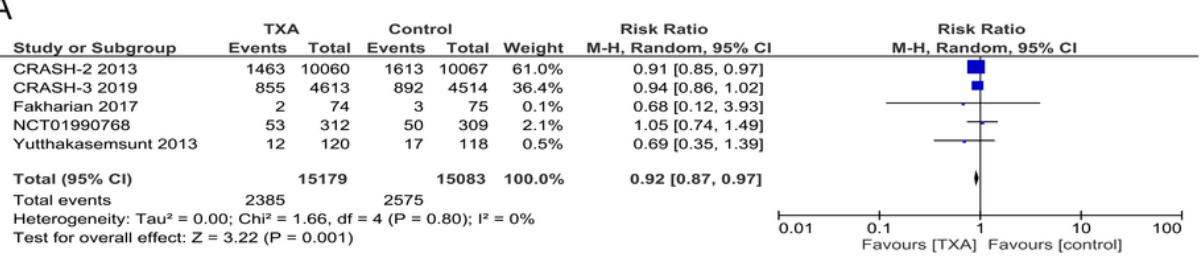

B
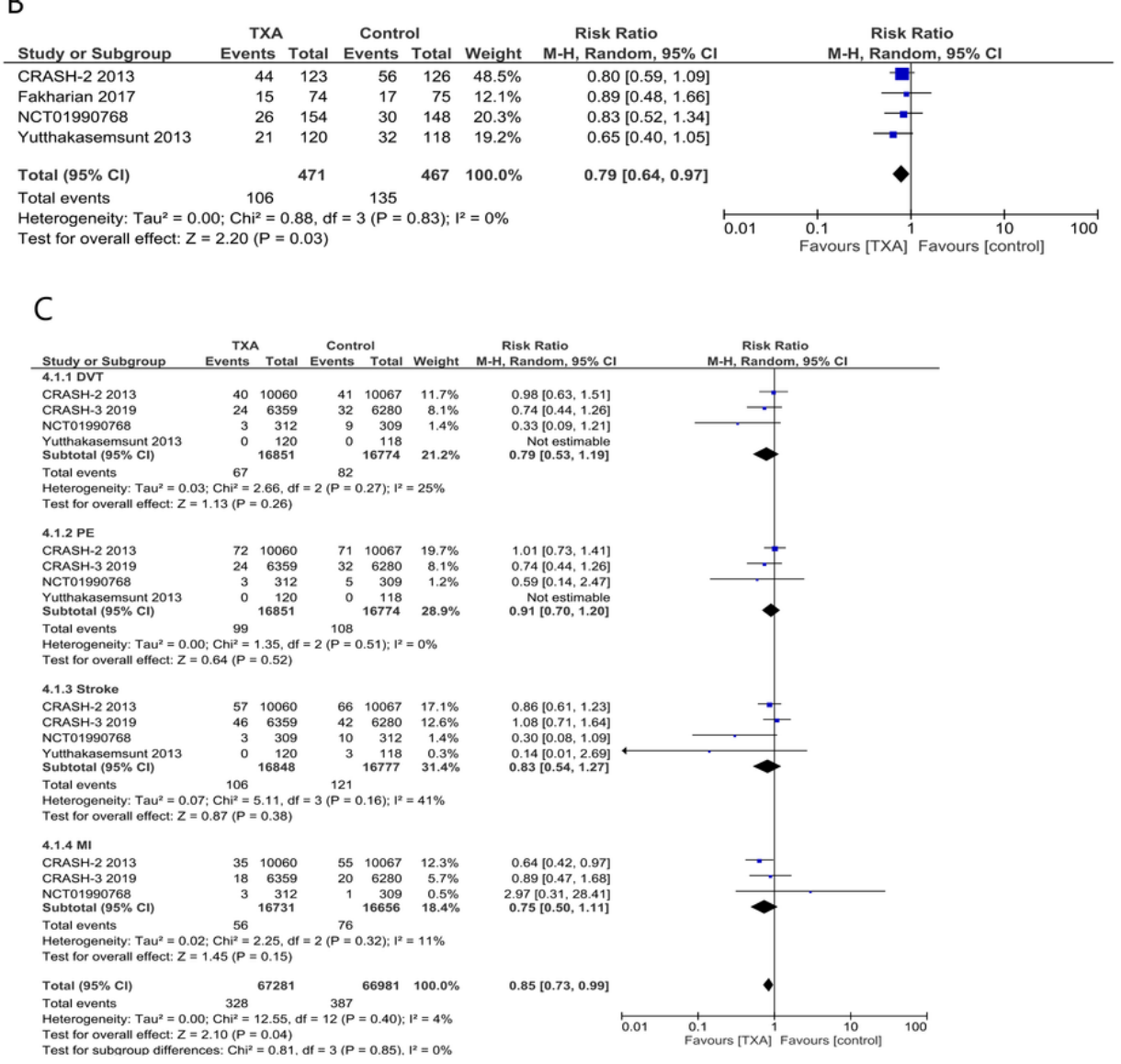

Figure 4

Subgroup analysis for studies with low risk of bias. Figure 4A demonstrated a lower mortality rate in TXA group. Figure 4B showed hemorrhagic expansion was less in TXA group. Vascular occlusive events (Figure 4C), defined as DVT+PE+stroke+MI was lower in TXA group. Description= DVT: Deep Vein Thrombosis; MI: Myocardial Infarction; PE: Pulmonary Embolism; TXA: Tranexamic Acid.

\section{Supplementary Files}

This is a list of supplementary files associated with this preprint. Click to download.

- PRISMASearchFlowchart.tif

- PRISMA2009checklist3.doc 